\title{
A CSAPADÉKVÍZ KEZELÉS JELENTŐSÉGE A VÁROSI KLIIMAADAPTÁCIÓBAN KECSKEMÉT PÉLDÁJÁN
}

\section{IMPORTANCE OF STORMWATER MANAGEMENT IN URBAN CLIMATE ADAPTATION IN KECSKEMÉT}

\author{
Hoyk Edit ${ }^{1,2^{*}}$ \\ ${ }^{1}$ Neumann János Egyetem Kertészeti és Vidékfejlesztési Kar, Agrárökonómiai és Vidékfejlesztési Tanszék, \\ Kecskemét, Magyarország \\ 2ELKH KRTK Regionális Kutatások Intézete, Alföldi Tudományos Osztály, Kecskemét, Magyarország \\ https://doi.org/10.47833/2021.1.AGR.001
}

\section{Kulcsszavak: \\ adaptáció \\ csapadékvíz menedzsment \\ esőkertek \\ klímaváltozás}

\section{Keywords:}

adaptation

climate change

rain gardens

stormwater management

\section{Cikktörténet:}

Beérkezett 2021. március 20.

Átdolgozva 2021. március 30.

Elfogadva 2021. április 5.

\begin{abstract}
Összefoglalás
Napjainkban sürgető feladat a városi csapadékvíz-menedzsment rendszerek kiépitése, amelyek segítségével megoldható a hirtelen lezúduló vízmennyiség tárolása, azok felhasználása; többek között öntözési célra, a zöld infrastruktúra fenntartására. Szükség van olyan projektek inditására, amelyek célja a csapadékvíz helyben történő beszivárgásának elösegítése, elszikkasztása. Utóbbi cél elérése érdekében a nemzetközi tapasztalatok alapján elsősorban az esőkertek kialakitása támogatandó.
\end{abstract}

Tanulmányunkban a csapadékvíz menedzsmenttel kapcsolatos tudnivalókat foglaljuk össze, amelynek egyik alkalmazható eszközét az esőkertek jelentik.

\begin{abstract}
Nowadays, it is an urgent task to build urban stormwater management systems, which can be used to store the sudden amount of water; e.g. for irrigation purposes or to maintain green infrastructure.

It is necessary to launch projects aimed at facilitating the infiltration and desiccation of rainwater locally. In order to achieve this goal, based on international experience, the development of rain gardens should be supported.

In our study, we summarize information about stormwater management, one of the applicable tools of which is rain gardens.
\end{abstract}

\section{Bevezetés}

A klímaváltozás magyarországi hatásai közül az egyik legnagyobb kihívást a csapadék szélsőségességének fokozódása jelenti. Ehhez nem csupán a mezőgazdaságnak nehéz alkalmazkodni, de az időről-időről jelentkező heves esőzések, a következményként kialakuló villámárvizek települési környezetben is nagy kihívást jelentenek az önkormányzatok számára. Emiatt sürgető feladat a városi csapadékvíz-menedzsment rendszerek kiépítése, amelyek

\footnotetext{
* Kapcsolattartó szerző. Tel.: +36 76516313

E-mail cím: hoyk.edit@kvk.uni-neumann.hu
} 
segítségével megoldható a hirtelen lezúduló vízmennyiség tárolása, azok felhasználása; többek között öntözési célra, a zöld infrastruktúra fenntartására.

A csapadékvíz-menedzsment egyik eleme az esőkertek kiépítése. Az esőkertek mesterségesen kialakított, mélyebb felszíneket jelentenek a talajban, funkciójuk az esővíz gyűjtése, ideiglenes tárolása és szürése, illetve a szikkasztás.

Kecskemét Megyei Jogú Város elkötelezett a klímaváltozáshoz való alkalmazkodás terén, amelynek fontos részét képezi az esőkertek kialakítása. Tanulmányunkban a csapadékvíz menedzsmenttel kapcsolatos tudnivalókat foglaljuk össze, illetve bemutatjuk azokat a lehetőségeket, amelyek Kecskemét számára adottak az adaptációs beruházásokon belül a csapadékvíz-kezelés területén.

\section{Irodalmi áttekintés}

A napjainkban tapasztalható, klímaváltozáshoz kötődő hatások között városi szinten az egyik legnagyobb probléma a csapadékvízhez kapcsolódik. Természetesen ezt a kérdést sem lehet önállóan vizsgálni, hiszen a (csapadék)víz hiánya, vagy éppen túlzott mennyisége már önmagában is kettős nehézséget jelent. Ezen kívül a zöld infrastruktúra fenntartása, amely az egyik leghatékonyabb eszköz a városi adaptációban, igen szorosan összefügg a csapadékkal, így a kettőt egymástól elválasztani nem lehet.

Az urbanizáció több, káros hidrológiai hatással jár, amelyek között a csapadékvíz kezelése összetett problémát jelent. A káros hatások csökkentése érdekében a bevált jó gyakorlatokat (Best Management Practice), illetve a kis beavatkozással járó fejlesztéseket (Low Impact Development) egyaránt szem elött kell tartani [6]. Számtalan lehetséges megoldás létezik, amelyek közül az esetek többségében különböző megoldások együttes alkalmazása szükséges a hatékony problémakezelés érdekében. A hagyományosnak tekinthető megoldás a csapadékvízgyűjtő csatornák kiépítése. Kecskemét esetében a város területének nagyobbik részén kiépült a csapadékvízgyűjtő csatornahálózat, ugyanakkor a jelenlegi körülmények között nem lehet csupán erre a rendszerre bízni a csapadékkezelést. A hálózat kiépítése rendkívül költséges, ami a vízkezeléssel foglalkozó társaságra, az önkormányzatra és a lakosságra egyaránt jelentős anyagi terhet ró. Ezen kívül nagy kérdést jelent a csatornák méretezése. Az elmúlt időszak villámárvizeket okozó csapadékeseményei (1. 2. ábrák) rávilágítottak arra, hogy olyan szélsőséges mennyiségü csapadékhullásokra lehet a jövőben egyre gyakrabban számítani, aminek az elvezetésére a meglévő csatornahálózat kapacitása nem alkalmas.

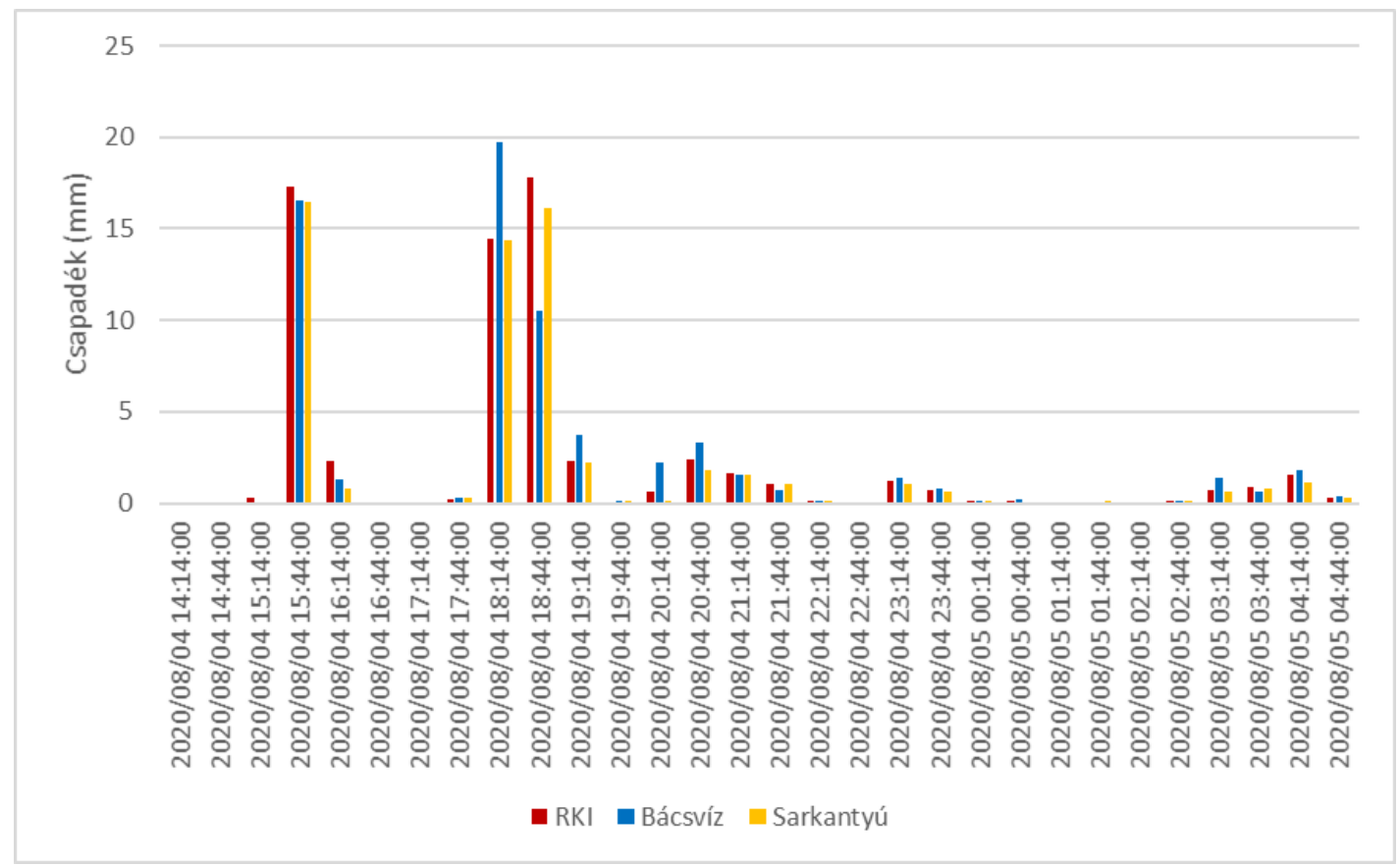

(Forrás: saját mérések)

1. ábra: Kecskeméten 12 óra alatt lehullott csapadékmennyiség (2020. augusztus 4-5.) 


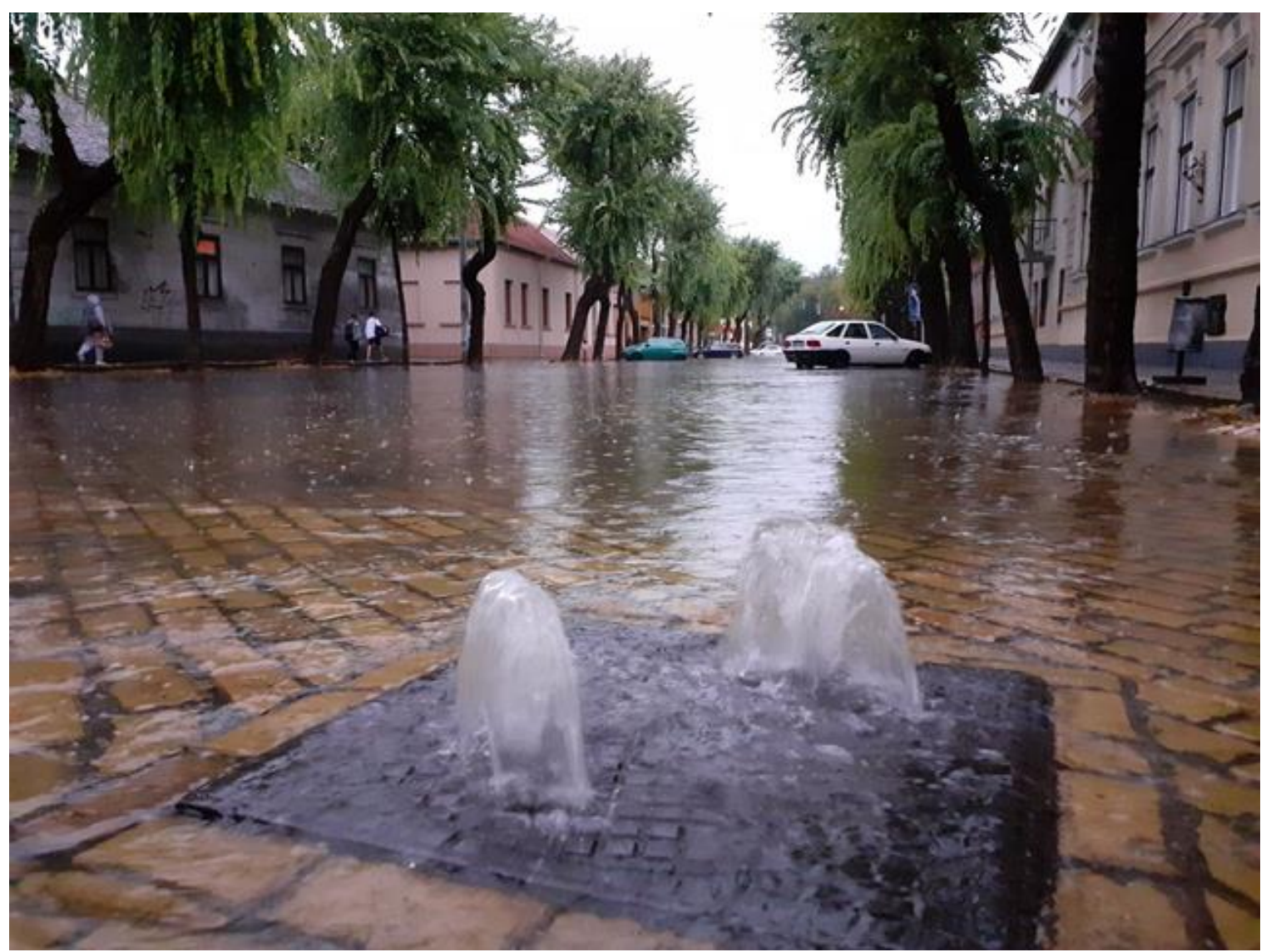

2. ábra: Villámárvíz Kecskeméten (2020. augusztus 4.)

(Forrás: hiros.hu)

A probléma összetettsége komplex kezelést igényel, amelynek érdekében szükség van a városi csapadékvízmenedzsment kialakítására. Ennek keretében olyan megoldások alkalmazhatók, amelyek rendszerben gondolkodva közelítik a problémát, és nem csupán arra koncentrálnak, hogyan lehet a többletvíztöl minél gyorsabban megszabadulni, ill. honnan lehet aszályos időszakokban öntözővízhez jutni.

A problémakör nemzetközi szinten már régóta ismert. A témával elsösorban azokban az országokban foglalkoztak korábban, ahol az éghajlat természetes jellemzője a rendkívül nagymennyiségű csapadékhullás, így pl. USA egyes területei, Nyugat-Európa óceáni éghajlatú térségei. Emiatt a lehetséges megoldások kidolgozása is ezekhez az országokhoz kötődik [1]; [2].

Városokban a probléma gyökere a burkolt felületek túlzott kiterjedése. A burkolatok megakadályozzák a csapadék talajba szivárgását, emiatt a teljes vízmennyiség elvezetésére van igény. Ez a megoldás azonban - amellett, hogy kivitelezhetetlen - a későbbiekben újabb nehézségeket okoz, hiszen csapadékszegény időszakokban a lehullott víz hiányozni fog, elsősorban a növényzet számára. Ezért a cél a csapadék talajba szivárgásának elösegítése. Ennek érdekében szükség van a burkolt felületek mennyiségének csökkentésére, vízáteresztő burkolatok alkalmazására, illetve olyan területek kialakítására, amelyek képesek a vizet ideiglenesen raktározni is. Utóbbira nyújtanak megoldást az esővíz gyüjtésére, ideiglenes tárolására, szikkasztására alkalmas esőkertek, amelyek a talajban mesterségesen kialakított mélyedések, növényekkel beültetve (3. ábra).

Az esőkertek kialakítása során olyan összefogásra van szükség, amelyben a települési önkormányzatok és a lakosság egyaránt elkötelezett a siker érdekében. Enélkül az esőkertprojektek kudarcra vannak ítélve [3].

Ami a gyakorlati kivitelezést illeti, a már meglévő tapasztalatokra érdemes építeni. Ebben megjelenik a méretezés kérdése, ami az adott terület vízgyüjtőjének nagyságától függ, vagy pl. a felhasznált anyagok (talajtípusok, komposzt, mulcsréteg) minősége. Minél kevésbé vízáteresztő az 
adott terület természetes talaja, annál nagyobb arányban van szükség komposzt hozzákeverésére [6].

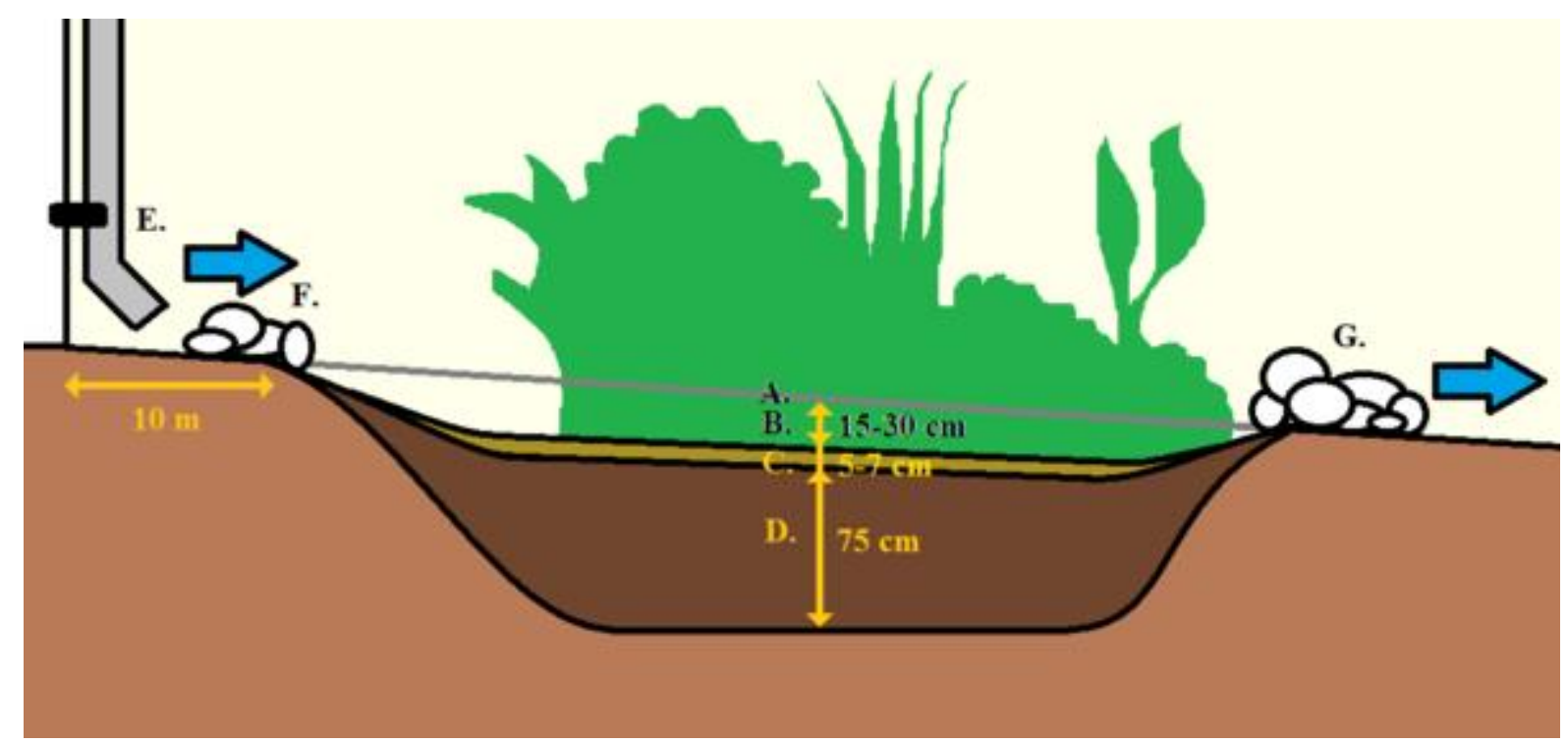

3. ábra: Esőkert vázlatos keresztmetszete

(Forrás: wikipedia.hu)

Az esőkertnek helyet adó mélyedés kialakításán túl nem elhanyagolható szempont az alkalmazott növények köre. A növények kiválasztásánál elsősorban azokat a tág tűrésü fajokat érdemes szem előtt tartani, amelyek elviselik az időszakos vízborítást, illetve a hosszabb aszályos periódusokat is. Napjainkig kevés tanulmány számszerüsítette, hogy az esőkertek hidrológiai teljesítményét hogyan befolyásolja a növényzet típusa. Azonban - mérési eredmények hiányában is - javasolható, hogy az esőkertek esetében taxonómiai és szerkezeti szempontból egyaránt sokszínű fajválasztás kerüljön előtérbe [5].

\section{Feladatok a csapadékvíz-kezelés területén}

Kecskemét esetében a klímaváltozás negatív hatásai közül a nyári höhullámok gyakoribbá válására, valamint a heves esőzések és az aszályos periódusok szélsőséges váltakozásaira kell elsősorban felkészülni. A csapadékkal kapcsolatban elmondható, hogy a városban és környékén a sokéves átlag 500-550 mm között mozog. Ez a mennyiség az elmúlt évtizedekben érdemben nem változott. Ugyanakkor a csapadék eloszlása rendkívül szélsőségessé vált. Egyes hónapokban a csapadék havi mennyisége mindössze 3-5 mm, míg egyes napokon a 12, illetve 24 óra alatt lehulló csapadékmennyiség a $60-80 \mathrm{~mm}$-t is eléri [4]. Emiatt egyre nagyobb figyelmet kell fordítani a csapadék kezelésére, a jelentős többletként jelentkező vízmennyiség tárolására, illetve az aszályos időszakokban a vízutánpótlásra. Napjainkban már nem megengedhető az a gyakorlat, ami a városra hulló csapadék és a tisztított szennyvíz Csukás-érbe vezetését jelenti, megfosztva ezzel a települést a szükséges vízmennyiségtől. A kialakítandó városi csapadékvíz menedzsment feladata a túlzott esőzések és a csapadékhiányos időszakok együttes kezelése.

A heves esőzések alkalmával lehulló vízmennységet meg kell tartani. Erre a felszíni és felszín alatti víztározók, valamint a kialakítandó esőkertek nyújtanak lehetőséget. Kecskemét a Duna-Tisza közi homokhátságon, átlagosan 110-120 m tengerszint feletti magasságban helyezkedik el. Fekvéséből következően a területén összegyülő vizek alapvetően a homokhátság pere, a Duna és a Tisza irányába folynak le. Ebből következően a vízmegtartás elösegítése a domborzati sajátosságok miatt is szükséges.

Fontos feladat az önkormányzat számára, hogy az extrém csapadékesemények hatására ne következzenek be zavarok a „kritikus infrastruktúrákban” (mint pl. úthálózat, áramellátás, vízellátás), de legalábbis e zavarok minél kisebb mértékűek legyenek. A csapadékvíz-kezelés tervezésekor az extrém időjárási jelenségek hatásait figyelembe kell venni, különösen a vízgazdálkodás és a csatornahálózat megfelelőségének vizsgálata során. Lényeges a nagymennyiségű csapadékvíz 
megfelelő elvezetésének, illetve helyben (a város közigazgatási határán belül) történő tárolásának és hasznosításának megoldása. További feladat a lakosság felkészítése a szélsőséges időjárási eseményekre és a klímaváltozás hatásaira.

A jelen kihívásaira adott megfelelő válaszok kidolgozása érdekében a csapadékvíz-kezelés terén városi szintű tervek készülnek, többek között esőkertek kialakítására. Az első kísérleti esőkert projekt a város egyik új építésű utcáját érinti, ahol a házak utcafrontja túlzott mértékben burkolt, a zöld növényzet pedig alárendelt szerepet játszik. Ebben a környezetben az intenzív esőzések az utca alacsonyabban fekvő részeinek, illetve a házak alagsorának víz alá kerülését eredményezik, emiatt elsőként ebben a környezetben kerül sor csapadékvíz-kezelési projekt megvalósítására. Annak érdekében, hogy a kialakítandó esőkert megfeleljen az elvárásoknak, a Bácsvíz Zrt., a Neumann János Egyetem Kertészeti és Vidékfejlesztési Kara, Kecskemét Megyei Jogú Város Önkormányzata, valamint a 10 millió FA civil szervezet együttesen kísérletet állít be. A kísérlet során vizsgáljuk az egyes talaj-komposzt arányok hatását a vízelnyelési képességre, valamint a különbözö növények és növénykombinációk alkalmazásának lehetőségeit.

\section{4. Összefoglalás}

A klímaváltozás negatív hatásai közül a városokat elsősorban a höhullámok következményei, az extrém intenzitású csapadékesemények, a szélsőségek fokozódása miatt jelentkező aszályos periódusok, valamint a zöld infrastruktúra kialakításának és fenntartásának nehézségei érintik.

Nemzetközi szinten a csapadékvíz menedzsment bevett gyakorlatnak számít. Hazai viszonylatban azonban kevés példát találunk a témában jól müködő gyakorlatra. A legfontosabb feladat - különösen a szárazodás hatásainak erősen kitett Kecskemét esetében - a csapadékvíz megtartása, illetve a szélsőségesen ingadozó csapadékhullásból eredő problémák (villámárvíz és aszály) kezelése.

A feladatok között szerepel a lehullott csapadék felszíni és felszín alatti tárolókban gyüjtése, valamint olyan projektek indítása, amelyek célja a csapadékvíz helyben történő beszivárgásának elösegítése, elszikkasztása. Utóbbi cél elérése érdekében a nemzetközi tapasztalatok alapján elsősorban az esőkertek kialakítása támogatandó. Ezek a létesítmények nem csupán a többlet csapadék kezelését tudják szolgálni, de jelentős mértékben gazdagítják a városi zöld infrastruktúrát is, ezen felül esztétikai értékük sem elhanyagolható.

\section{Köszönetnyilvánítás}

Köszönettel tartozunk a kutatás támogatásáért, amely az EFOP-3.6.1-16-2016-00006 „A kutatási potenciál fejlesztése és bővítése a Neumann János Egyetemen" pályázat keretében valósult meg. A projekt a Magyar Állam és az Európai Unió támogatásával, az Európai Szociális Alap társfinanszírozásával, a Széchenyi 2020 program keretében valósul meg.

\section{Irodalomjegyzék}

[1] Asleson, B.C. - Nestingen, R.S. - Gulliver, J.S. - Hozalski, R.M. - Nieber, J.L. (2009): Performance assessment of rain gardens. Journal of the American Water Resources Association. Vol. 45., No. 4., pp. 1019-1031. https://doi.org/10.1111/j.1752-1688.2009.00344.x

[2] Autixier, L. - Mailhot, A. - Bolduc, S. - Madoux-Humery, A.S. - Galarneau, M. - Prévost, M. - Dorner, S. (2014): Evaluating rain gardens as a method to reduce the impact of sewer overflows in sources of drinking water. Science of The Total Environment. Volume 499, pp. 238-247. https://doi.org/10.1016/i.scitotenv.2014.08.030

[3] Chaffin, B.C., et al. (2016): A tale of two rain gardens: Barriers and bridges to adaptive management of urban stormwater in Cleveland, Ohio, Journal of Environmental Management http://dx.doi.org/10.1016/j.jenvman.2016.06.025

[4] Hoyk, E. - Kanalas, I. - Farkas, J.Zs. (2020): Environmental changes in Kecskemét between 2009-2018. Gradus, Vol 7, No 2. pp. 1-5.

[5] Yuan, J. - Dunnett, N. - Stovin, V. (2017): The influence of vegetation on rain garden hydrological performance. Urban Water Journal, Vol. 14, Issue 10. https://doi.org/10.1080/1573062X.2017.1363251

[6] Zhang, S. - Guo, Y. M.ASCE (2013): Explicit Equation for Estimating Storm-Water Capture Efficiency of Rain Gardens. Journal of Hydrologic Engineering. 18:1739-1748. https://doi.org/10.1061/(asce)he.1943-5584.0000734 